\title{
A freeze-etch study of dense fibres in rat spermatozoa
}

\author{
T. Espevik and A. Elgsaeter \\ Institute of Biophysics, The Norwegian Institute of Technology, N-7034 Trondheim-NTH, \\ Norway
}

\begin{abstract}
Summary. The presence of oblique striations on the cortex of the dense fibres of the rat spermatozoon is confirmed; they have a main periodicity of approximately $40 \mathrm{~nm}$ and a secondary one of about $20 \mathrm{~nm}$. Disruption of spermatozoa by Triton X-100 and dithiothreitol and fixation in glutaraldehyde do not affect the pattern. The dense fibre cortex appears to consist of globular substructure units with a diameter of about $19 \mathrm{~nm}$.
\end{abstract}

\section{Introduction}

The dense fibres are the dominant feature of the tail of the spermatozoon although their role is unknown (Fawcett, 1975). In the rat, the fibres consist of a thin cortical layer and a thick medulla. The cortex appears to be highly ordered in whole mounts (Woolley, 1971), in replicae of critical pointdried spermatozoa (Olson, 1973) and in thin sections (Phillips, 1975). Woolley (1971) and Phillips \& Olson (1975) have described oblique striations of the cortex of the dense fibres in specimens of rat spermatozoa subjected to dehydration and desiccation. We have now studied the dense fibres of rat spermatozoa by a freeze-etching technique which eliminates such artefacts.

\section{Materials and Methods}

Adult male Wistar rats ( 2 months old) were used. The animals were killed by decapitation or by exposure to ether vapour. The cauda or caput epididymidis was gently minced at $0-4^{\circ} \mathrm{C}$ with a razor blade and spermatozoa were expressed into phosphate-buffered saline (PBS), pH 7.6, containing $8 \mathrm{~mm}$-phosphate buffer and $145 \mathrm{mM}-\mathrm{NaCl}$. The spermatozoa were then pelleted by centrifugation at $1500 \mathrm{~g}$ for $5 \mathrm{~min}$ at $22^{\circ} \mathrm{C}$ and partly resuspended in a few drops of PBS at $0-4^{\circ} \mathrm{C}$ before $1-2 \mu \mathrm{l}$ droplets were taken out and frozen for freeze-etching as described by Southworth, Fisher \& Branton (1975). Some sperm pellets were resuspended in $10 \mathrm{ml}$ of a buffer at $\mathrm{pH} 9.0$ containing $0.5 \%$ Triton X-100, $100 \mathrm{~mm}-\mathrm{NaCl}, 5 \mathrm{~mm}-\mathrm{MgCl}_{2}, 2 \mathrm{~mm}$-dithiothreitol, $1 \mathrm{~mm}$-ATP and $20 \mathrm{~mm}$-Tris (Olson \& Linck, 1977) and incubated for $30 \mathrm{~min}$ at $0-4^{\circ} \mathrm{C}$. The spermatozoa were then pelleted at $1500 \mathrm{~g}$ for $5 \mathrm{~min}$ at $22^{\circ} \mathrm{C}$ and the pellet was washed twice in $10 \mathrm{ml}$ PBS before freezing for freeze-etching. Some samples were fixed in $2 \%$ vacuum-distilled glutaraldehyde in PBS for $30 \mathrm{~min}$ at $2^{\circ} \mathrm{C}$ before freezing. The freeze-etching was carried out with the unit described by Elgsaeter (1978). After cleaning with clorox the replicas were washed and mounted on 200-mesh copper grids and observed in a Jeol 100B or a Philips 300 electron microscope. The optical diffraction was effected on a diffractometer equipped with a $3 \mathrm{mV}$ He-Neon laser (Horne \& Markham, 1972).

\section{Results and Discussion}

No significant ultrastructural differences were observed on the dense fibres of the spermatozoa obtained from the cauda or caput epididymidis respectively (Pl. 1, Figs 1 and 2; Pl. 2, Figs 3 and 4). The general appearance of the dense fibres was the same whether or not the spermatozoa were fixed with glutaraldehyde before freezing for freeze-etching or when Triton X-100 extraction was followed by glutaraldehyde fixation (Pl. 2, Fig. 5). The Triton X-100 solution with dithiothreitol and ATP gave rise to a partial breakdown of the spermatozoa. At the light microscope level there was a fraying of 
the sperm tail with an extrusion of fibres from the lumen of the fibrous sheath. Freeze-etch electron microscopy of these samples confirmed that the fibres seen in the light microscope were the dense fibres and that they were separated from the rest of the tail. A large number of extended surface views of the dense fibres was therefore seen in specimens treated with Triton X-100, dithiothreitol and ATP, but such views were rarely seen when Triton X-100 was not used.

The period of the main striations, measured perpendicularly to the structures, was found to be $40 \mathrm{~nm}$, and that of the minor striations was about $20 \mathrm{~nm}$. The presence of a major and a minor periodicity on the dense fibre, the one having a period twice that of the other, is also indicated by the optical diffraction pattern (Pl. 2, Fig. 5). Any difference in the periodicity of the unfixed fibre shown in Pl. 1, Fig. 1, and the detergent-treated and fixed fibre shown in Pl. 2, Fig. 5 was less than $2-3 \%$. No periodic structures were observed in cross- or longitudinal-fracture planes through the medulla. In some crossfractures of the dense fibres globular subunits, with a diameter of about $19 \mathrm{~nm}$, could be seen on the cortex (Pl. 2, Fig. 4).

The striations described are similar to and have the same direction of obliqueness as those observed by Woolley (1971), who reported a periodicity of $39.8 \mathrm{~nm}$ for the dense fibres of rat spermatozoa. Woolley (1971) suggested that the periodicity may represent a space where material was present in situ but removed due to differential hydration of protein during fixation. Since the oblique striations can also be observed on the dense fibres of freeze-etched spermatozoa, this interpretation can be ruled out and there is no reason to believe that the dense fibre oblique striations are not genuine.

This work has been supported in part by grants from the Ford Foundation (770-0538) and the Norges Tekniske Høgskoles Fond. We thank Professor K. B. Eik-Nes for help.

\section{References}

Elgsaeter, A. (1978) A new freeze-etch unit for freezeetch rotary shadowing, low temperature freezefracturing and conventional freeze-etching. $J$. Microsc. (in press).

FAWCETT, D.W. (1975) The mammalian spermatozoon. Devl Biol. 44, $394-436$.

HoRne, R.W. \& MARKhAM, R. (1972) Lens requirements and construction of an optical diffractometer for electron microscopy. In Practical Methods in Electron Microscopy, Vol. 1, Part 2, Chapter 3, pp. 347-360. Ed. A. M. Glauert. North-Holland, Amsterdam.

OLson, G. (1973) Surface structure revealed by replicas of critical-point dried spermatozoa.J. Cell Biol.59, 254a.

Olson, G.E. \& LincK, R.W. (1977) Observations of the structural components of flagellar axonemes and central pair microtubules from rat sperm. J. Ultrastruct. Res. 61, 21-43.
PhILLIPS, D.M. (1975) Mammalian sperm structure. In Handbook of Physiology, Vol. 5, Section 7, Chapter 19, pp. 405-419. Eds R. O. Greep \& E. B. Astwood. Am. Physiol. Soc., Washington, D.C.

Phillips, D.M. \& Olson, G. (1975) Mammalian sperm motility-structure in relation to function. In The Functional Anatomy of the Spermatozoon, pp. 117-126. Ed. B. A. Afzelius. Pergamon Press, Oxford.

Southworth, D., Fisher, K. \& Branton, D. (1975) Principles of freeze-fracturing and etching. In Techniques of Biochemical and Biophysical Morphology, pp. 247-282. Eds D. Glick \& R. Rosenbaum. Wiley, New York.

WoOLLEY, D.M. (1971) Striations in the peripheral fibres of rat and mouse spermatozoa. J. Cell Biol. 49, 936939.

Received 6 April 1978 

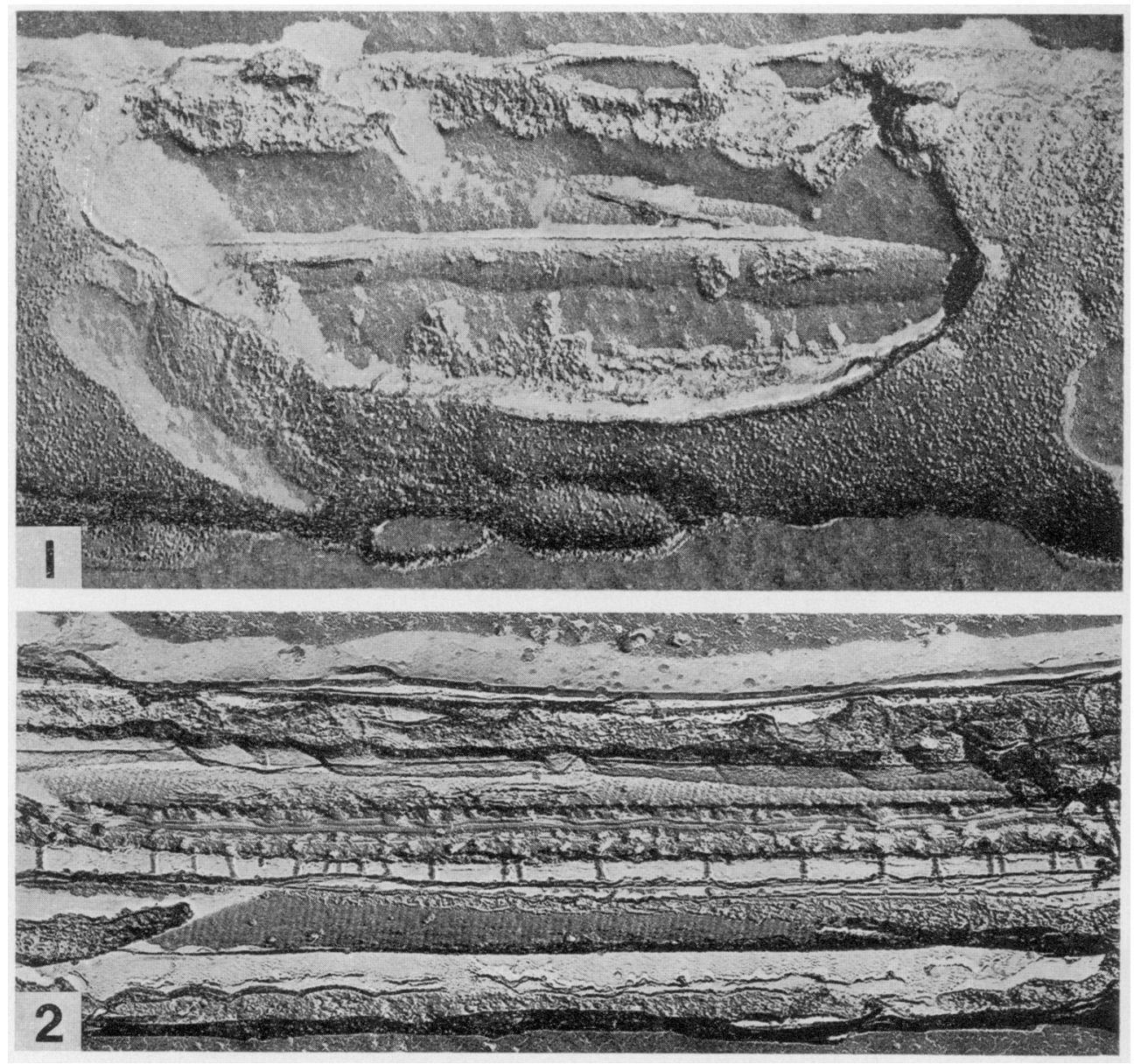

The shadow direction is from bottom to top and the shadows are white.

Fig. 1. Unfixed rat spermatozoon in PBS isolated from the cauda epididymidis. Longitudinal fracture through the sperm midpiece exhititing dense fibre surfaces. Etching at $-98^{\circ} \mathrm{C}$ for 1 min at $1 \times 10^{-6}$ Torr. $\times 50700$.

Fig. 2. Unfixed rat spermatozoon in PBS isolated from cauda epididymidis. Longitudinal fracture through the sperm midpiece showing the dense fibre surfaces and fractures through the medulla. Etching at $-98^{\circ} \mathrm{C}$ for $1 \mathrm{~min}$ at $1 \times 10^{-6}$ Torr. $\times 43700$. 
PLATE 2
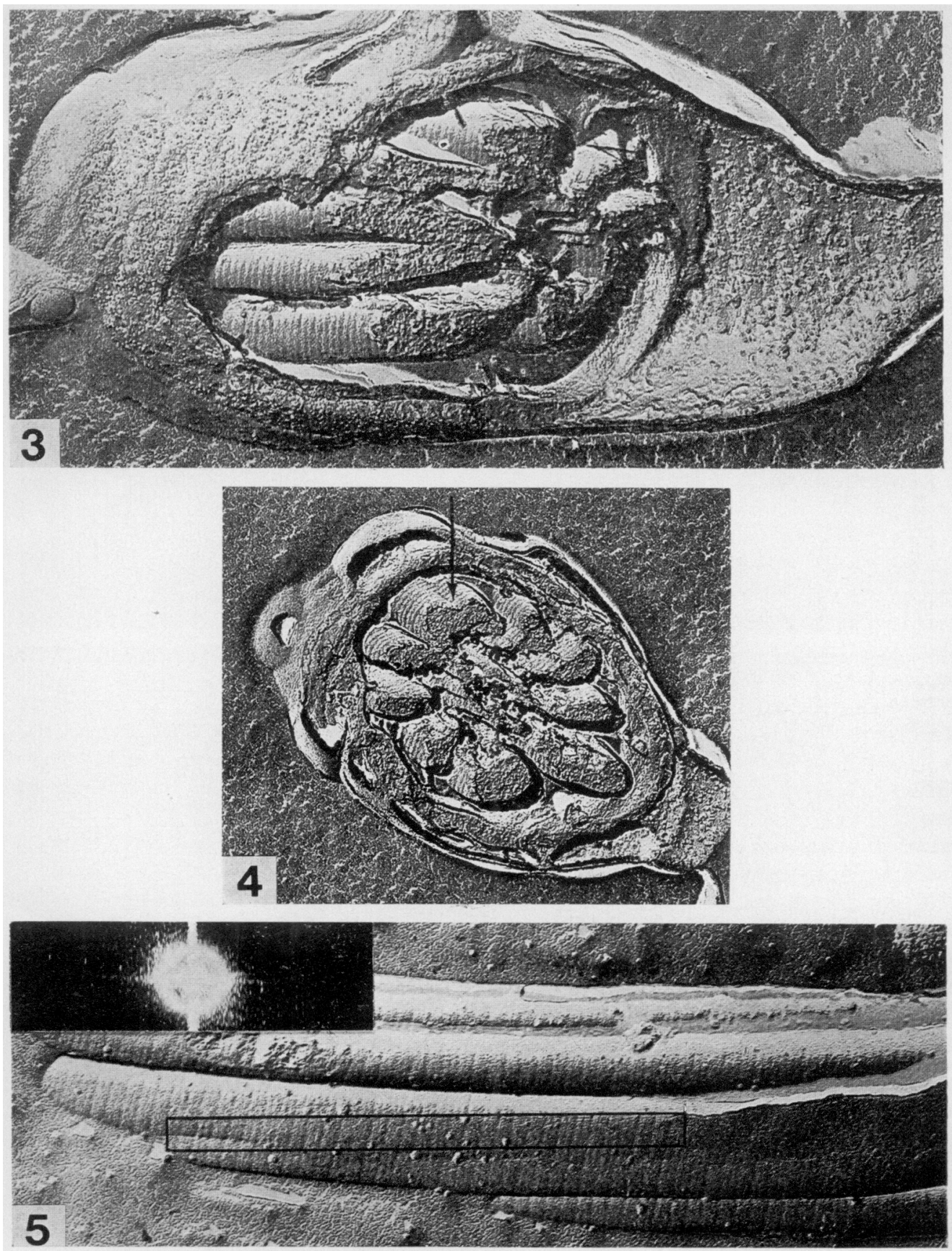

The shadow direction is from bottom to top and the shadows are white.

Fig. 3. Unfixed rat spermatozoon in PBS isolated from the cauda epididymidis. Cross-fracture through the sperm midpiece. Etching at $-98^{\circ} \mathrm{C}$ for $1 \mathrm{~min}$ at $1 \times 10^{-6}$ Torr. $\times 51300$.

Fig. 4. Unfixed rat spermatozoon in PBS isolated from the cauda epididymidis. Cross-fracture through the sperm midpiece showing the globular structures at the dense fibre medulla (arrow). Etching at $-98^{\circ} \mathrm{C}$ for $1 \mathrm{~min}$ at $1 \times 10^{-6}$ Torr. $\times 41400$.

Fig. 5. Rat spermatozoon isolated from the cauda epididymidis. Etched surface of the dense fibres after extraction with Triton X-100 and fixation in $2 \%$ glutaraldehyde. The optical diffraction pattern is that obtained from the area indicated by the rectangle. Etching at $-102^{\circ} \mathrm{C}$ for 1 min at $1 \times 10^{-6}$ Torr. $\times 53000$. 